\title{
Malignant Germ Cell Tumor
}

National Cancer Institute

\section{Source}

National Cancer Institute. Malignant Germ Cell Tumor. NCI Thesaurus. Code C4925.

A gonadal or extragonadal malignant neoplasm that arises from germ cells.

Representative examples include embryonal carcinoma, yolk sac tumor, and seminoma. 